\title{
EVALUASI KINERJA PENDAMPINGAN DAN PENGAWALAN TEKNOLOGI PADA KIMBis CAKRADONYA, BANDA ACEH
}

\author{
Estu Sri Luhur dan Armen Zulham \\ Balai Besar Penelitian Sosial Ekonomi Kelautan dan Perikanan \\ JI. KS. Tubun Petamburan VI Jakarta 10260 \\ Telp. (021) 53650162, Fax. (021)53650159 \\ e-mail: s2luhur@yahoo.co.id \\ Diterima 18 Februari 2013 - Disetujui 25 Mei 2013
}

\begin{abstract}
ABSTRAK
Tulisan ini bertujuan untuk mengevaluasi kinerja dari kegiatan pendampingan dan pengawalan teknologi yang telah dilakukan pada KIMBis Cakradonya di Banda Aceh. Evaluasi dilakukan mencakup kegiatan yang dilaksanakan selama periode Agustus - November 2012. Evaluasi kinerja ini diukur dengan menggunakan kuesioner terstruktur dengan jawaban yang tertutup untuk mengetahui persepsi peserta terhadap kegiatan yang dilaksanakan. Pelaksanaan evaluasi kegiatan dilaksanakan pada 38 responden. Aspek yang dievaluasi terdiri dari aspek peran pengurus KIMBis, keragaman materi, kemampuan instruktur, keseriusan peserta dan aspek lainnya. Hasil evaluasi menunjukkan kegiatan pendampingan teknologi yang dilakukan telah sangat baik. Aspek yang dinilai adalah aspek peran pengurus, isi materi dan kemampuan instruktur karena materi yang diberikan sudah sesuai dengan kebutuhan peserta dan mampu ditransfer dengan baik oleh instruktur. Namun, aspek yang dinilai cukup adalah aspek jumlah peserta kegiatan. Aspek ini menunjukkan bahwa jumlah peserta perlu ditambah karena materi yang diberikan sangat bermanfaat bagi pengembangan ekonomi masyarakat. Aspek lain yang perlu diperhatikan bahwa peralatan dan bahan praktek yang disediakan pengurus dinilai masih terbatas. Evaluasi ini merekomendasikan untuk pelaksanaan kegiatan yang terkait dengan penyediaan alat dan bahan dan pengurus KIMBis harus berkoordinasi dengan SKPD terkait di Kota Banda Aceh.
\end{abstract}

Kata kunci: evaluasi kinerja, teknologi, KIMBis

Abstract : Performance Evaluation for Escort of Technology in KIMBis Cakradonya, Banda Aceh. By : Estu Sri Luhur dan Armen Zulham.

This paper aimed to evaluate the performance for escort of technology that has been done by KIMBis Cakradonya in Banda Aceh during August - November 2012. Evaluation of performance is measured using a closed questionnaire to the participants in the perception by 38 people. Evaluated consists of the aspects of KIMBis caretaker role, diversity of material, instructors' skill, seriousness of the participants and other aspects. Evaluation showed that on average the participants in assessing the escort of technology has been very well done. The aspect that is considered to be very good was an aspect of the caretaker role, material content and instructors' skill because the materials provided are in accordance with the needs of the participants and was able to be transferred either by the instructor. However, it was considered good aspect is the aspect of the number of participants in all three escorts because participants expect more number of participants since the material provided is very beneficial for the economic development of the community. Other aspects are also considered good in all three escorts for the equipment and materials provided by the management practice is still considered limited. This evaluation recommended for the implementation of activities related to the supply of equipment and materials and KIMBis administrators should coordinate with related local government offices in Banda Aceh.

Keywords : evaluation of performance, technology, KIMBis

\section{PENDAHULUAN}

Kota Banda Aceh merupakan salah satu kawasan yang hancur karena tsunami pada tanggal 26 Desember 2004. Bencana tersebut menghancurkan infrastruktur, pemukiman, sarana dan prasarana serta merusak ekosistem pesisir Kota Banda Aceh. Dampak kerusakan bio-fisik tersebut telah mengubah keseimbangan sosial, ekonomi dan budaya serta lingkungan masyarakat di kawasan ini (Sari et al., 2006). Keseimbangan tersebut berpengaruh pada proses produksi usaha penangkapan ikan, pengolahan ikan dan budidaya kepiting soka, ikan dan udang. Setelah tsunami seluruh usaha tersebut digerakkan oleh usaha dengan skala rumah tangga
(Dinas Kelautan, Perikanan dan Pertanian Kota Banda Aceh, 2012).

Kawasan pesisir Kota Banda Aceh merupakan salah satu kawasan produksi perikanan yang menjadi fokus perhatian untuk dikembangkan menjadi kawasan pengembangan usaha perikanan karena memiliki potensi yang besar. Berdasarkan data PDRB atas dasar harga konstan pada tahun 2011, perikanan merupakan salah satu subsektor pada sektor pertanian yang memiliki kontribusi terbesar dibandingkan subsektor lainnya, yaitu sebesar 1,92 persen. Hal ini disebabkan oleh karena wilayah Kota Banda Aceh yang dikelilingi oleh laut dengan mayoritas penduduk di sekitar pesisir 
pantai merupakan nelayan atau berusaha di sektor perikanan dan kelautan (BPS, 2012).

Selain memiliki potensi perikanan, kawasan pesisir yang berhadapan dengan Selat Malaka tersebut juga memiliki potensi untuk dikembangkan sebagai kawasan pariwisata, pengembangan usaha perikanan, serta jasa kelautan dan transportasi. Berbagai potensi tersebut jika disentuh dengan inovasi kelembagaan dan IPTEK dapat dimanfaatkan untuk meningkatkan perekonomian masyarakat setempat (Commothio, 2010). Inovasi kelembagaan tersebut merupakan transformasi penting dalam medorong berbagai bentuk usaha skala rumah tangga menjadi sebuah usaha ekonomi yang mandiri. Wadah untuk transformasi tersebut adalah Klinik IPTEK Mina Bisnis (KIMBis). Wadah ini diharapkan dapat mendorong transformasi ekonomi masyarakat dari usaha rumah tangga menuju usaha yang berorientasi pasar, sehingga dapat membuka lapangan kerja dan sumber pendapatan bagi masyarakat. Transformasi usaha seperti ini merupakan salah satu indikator terjadinya pembangunan perekonomian wilayah (Drajat, 2013).

Pada awal Agustus 2012, wadah untuk mendorong transformasi ini telah terbentuk dengan nama KIMBis Cakradonya yang berlokasi di Gampong Pande, Kecamatan Kuta Raja. KIMBis Cakradonya merupakan kelembagaan resmi yang dibuat berdasarkan kerja sama dari berbagai pemangku kepentingan.

Peran KIMBis Cakradonya dalam transformasi ini: pertama, terkait dengan pembinaan dan pendampingan pengembangan kewirausahaan dengan memanfaatkan teknologi. Kedua, memfasilitasi kepentingan sumber teknologi dan pengguna teknologi (pelaku usaha). Dengan dua peran tersebut maka KIMBis Cakradonya merupakan wadah pemberdayaan masyarakat dalam meningkatkan taraf hidup dengan memanfaatkan teknologi tepat guna dan menumbuhkan kewirausahaan sehingga mendorong kemandirian dalam mengembangkan perekonomian di perdesaan (Zulham, 2011). Untuk menjalankan peran tersebut, Klinik IPTEK Mina Bisnis (KIMBis) lebih berfungsi sebagai pusat pemberdayaan masyarakat. Pusat pemberdaaan masyarakat tersebut akan berfungsi jika memenuhi 4 (empat) kriteria, yaitu: (1) inklusi dan partisipasi; (2) akses pada informasi; (3) meningkatkan kapasitas organisasi lokal; (4) profesionalitas pelaku pemberdaya (Dewanto, 2004). Pusat pemberdayaan masyarakat tersebut merupakan lembaga yang mendorong, mengembangkan, memandirikan, menswadayakan, memperkuat posisi tawar-menawar masyarakat dalam perekonomian dan pembangunan (Sutoro, 2002). Sementara itu menurut Permendagri No. 7 Tahun 2007, pemberdayaan masyarakat merupakan suatu strategi yang digunakan dalam pembangunan sebagai upaya untuk mewujudkan kemampuan dan kemandirian dalam kehidupan bermasyarakat, berbangsa dan bernegara (Pasal 1 Ayat 8).
Menurut Semiaji (2011), pemberdayaan mengarah pada upaya memandirikan dan meningkatkan kemampuan masyarakat serta membangkitkan kesadaran akan kemampuan yang dimiliki untuk maju ke arah kehidupan yang lebih baik dan berkelanjutan (sustainable). Untuk itu, implementasi dari pemberdayaan masyarakat pada KIMBis salah satunya dilakukan melalui kegiatan pendampingan dan pengawalan teknologi sehingga usaha masyarakat perikanan dapat berkembang secara mandiri. Oleh sebab itu, tujuan dari tulisan ini adalah untuk melakukan evaluasi terhadap pelaksanaan dan pendampingan teknologi melalui pemberdayaan masyarakat di dalam kegiatan KIMBis.

\section{METODOLOGI}

\section{Jenis Kegiatan}

Kegiatan yang dievaluasi meliputi: 1) kegiatan pendampingan teknologi perbenihan lele secara buatan; 2) kegiatan pendampingan teknik pengolahan hasil perikanan; 3) kegiatan pendampingan teknik perbengkelan mesin kapal. Cakupan evaluasi meliputi: (1) persiapan pengurus; (2) keragaman materi dalam kegiatan tersebut; (3) persepsi terhadap instruktur; (4) pemilihan peserta pelatihan; (5) faktor lain-lainnya.

\section{Lokasi dan Waktu Kegiatan}

Lokasi pelaksanaan evaluasi di KIMBis Cakradonya Banda Aceh. Ketiga kegiatan dilaksanakan selama periode Agustus - November 2012 di Kota Banda Aceh.

\section{Teknik Pengumpulan Data dan Jenis Data}

Pengumpulan data dilakukan dengan cara sensus kepada seluruh peserta yang mengikuti kegiatan pendampingan teknologi. Peserta tersebut mengisi kuesioner yang telah disediakan dengan jawaban yang tertutup. Jumlah peserta yang menjadi responden sebanyak 38 orang yang terdiri dari peserta pembudidaya sebanyak 11 orang, peserta pengolah sebanyak 15 orang dan peserta nelayan sebanyak 12 orang.

\section{Metode Analisis Data}

Data yang dikumpulkan dianalisis mengggunakan indeks Linkert dengan skala 1-2. Skala 1 menggambarkan persepsi responden terhadap aspek yang dipelajari sesuai dengan yang diinginkan dan skala 2 sebaliknya. Data hasil olahan ditampilkan dalam tabulasi statistk sederhana.

\section{KEGIATAN PENDAMPINGAN DAN PENGAWALAN TEKNOLOGI}

Kegiatan pendampingan dan pengawalan teknologi tepat guna pada pelaku usaha perikanan melalui penerapan IPTEK, secara empiris telah 
membuktikan dapat meningkatkan kuantitas dan kualitas usaha masyarakat pada berbagai lokasi pemberdayaan masyarakat melalui KIMBis.

Kegiatan pendampingan teknologi yang telah dilakukan di Kota Banda Aceh, terdiri dari pendampingan teknologi perbenihan ikan lele, teknologi pengolahan hasil perikanan, dan teknologi perbengkelan. Kegiatan pendampingan dan pengawalan teknologi ini merupakan implementasi teknologi hasil dari paket teknologi perbenihan dan pengolahan hasil perikanan yang sederhana dan mudah diaplikasikan oleh pelaku usaha perikanan.

Pelaksanaan pendampingan dan pengawalan teknologi tersebut diharapkan dapat: (1) meningkatkan kapasitas dan keterampilan kelompok sasaran; (2) memperkenalkan dan mempromosikan teknologi baru yang akan dikembangkan, pengguna kepada kelompok sasaran dan tersedia di pasaran; (3) memberikan akses kepada kelompok sasaran untuk berinteraksi dengan sumber-sumber teknologi; (4) memperkaya pilihan teknologi; (5) mengetahui informasi pasar.

Komponen penting dari pendampingan dan pengawalan teknologi dalam pemberdayaan masyarakat adalah: a) teknologi tepat guna; b) inovator dalam kelompok sasaran; c) dukungan politis pelaksanaan kegiatan tersebut.

\section{Pendampingan Teknologi Perbenihan Lele Secara Induksi}

Paket teknologi perbenihan lele secara induksi disampaikan oleh narasumber dari Balai Budidaya Air Payau Ujung Batte, Kementerian Kelautan dan Perikanan. Teori perbenihan ikan lele yang disampaikan oleh narasumber menjelaskan bahwa melakukan pemijahan ikan lele secara induksi, pembesaran larva dan pasar benih bukan merupakan hal yang sulit untuk dikerjakan.
Perbenihan ikan lele ini diperkenalkan karena $70 \%$ benih dan lele konsumsi yang masuk ke Kota Banda Aceh berasal dari Kota Medan melalui pedagang lele lokal. Selain itu, komoditas ini mudah dibudidayakan dalam lingkungan yang cukup ekstrem serta segmen pasarnya makin luas.

Pengawalan teknologi tersebut dapat memotivasi pelaku usaha perbenihan dan budidaya lele di Kota Banda Aceh untuk serius dalam melakukan usaha tersebut. Materi perbenihan lele seperti paada Tabel 1 terdiri dari dua jenis, yaitu teori dan praktik. Teori perbenihan lele mencakup tiga hal, yaitu perbenihan lele, menajemen induk lele dan pengelolaan kualitas perbenihan ikan lele. Sementara itu, praktik perbenihan lele mencakup teknik pemilihan induk lele sampai dengan cara pembesaran larva lele (Tabel 1).

Ikan lele merupakan komoditas yang sangat resisten terhadap lingkungan sehingga perbenihan ikan lele dapat dilakukan di lahan-lahan terbatas dengan menggunakan kolam yang terbuat dari bahan sederhana, yaitu kayu kaso bekas dengan plastik terpal dan lahan tanah dengan plastik terpal.

Peserta yang terlibat dalam kegiatan perbenihan sebagian besar merupakan pelaku usaha pembudidaya ikan lele dan peminat baru. Peserta kegiatan paket teknologi perbenihan ikan lele dapat dilihat pada Gambar 2.

Melalui pendampingan teknologi ini peserta diharapkan mampu memahami segmen agribisnis ikan lele. Tingkat kesuksesan bisnis lele, baik pada segmen perbenihan maupun pembesaran sangat bergantung pada pemahaman pelaku usaha dalam mengoptimalkan teknologi perbenihan yang digunakan. Jika peserta dapat memproduksi benih lele maka usaha budidaya lele di masyarakat makin efisien dan keuntungan yang diperoleh oleh pelaku usaha, serta biaya pembelian benih makin murah.

Tabel 1. Materi Pendampingan Perbenihan Lele Secara Buatan di KIMBis Kota Banda Aceh.

\section{MATERI}

1. Teori perbenihan lele

2. Teori manajemen induk lele

3. Teori pengelolaan kualitas dalam perbenihan ikan lele

1. Teknik pemilihan induk lele, model kolam induk lele, pakan dan manajemen pemberian pakan induk lele

2. Metode pemijahan (pemeriksaan kematangan gonad, wadah pemijahan) lele

1. Teknik penyuntikan, pengambilan gonad, striping induk betina, mencampurkan sperma dan telur, serta cara tebur campuran telur dan sperma induk lele

2. Teknik inkubasi telur lele

3. Teknik pembesaran larva lele

Diskusi tentang hasil pendampingan dan pengawalan IPTEK perbenihan lele

Sumber: Bahan Presentasi Kegiatan, 2012 


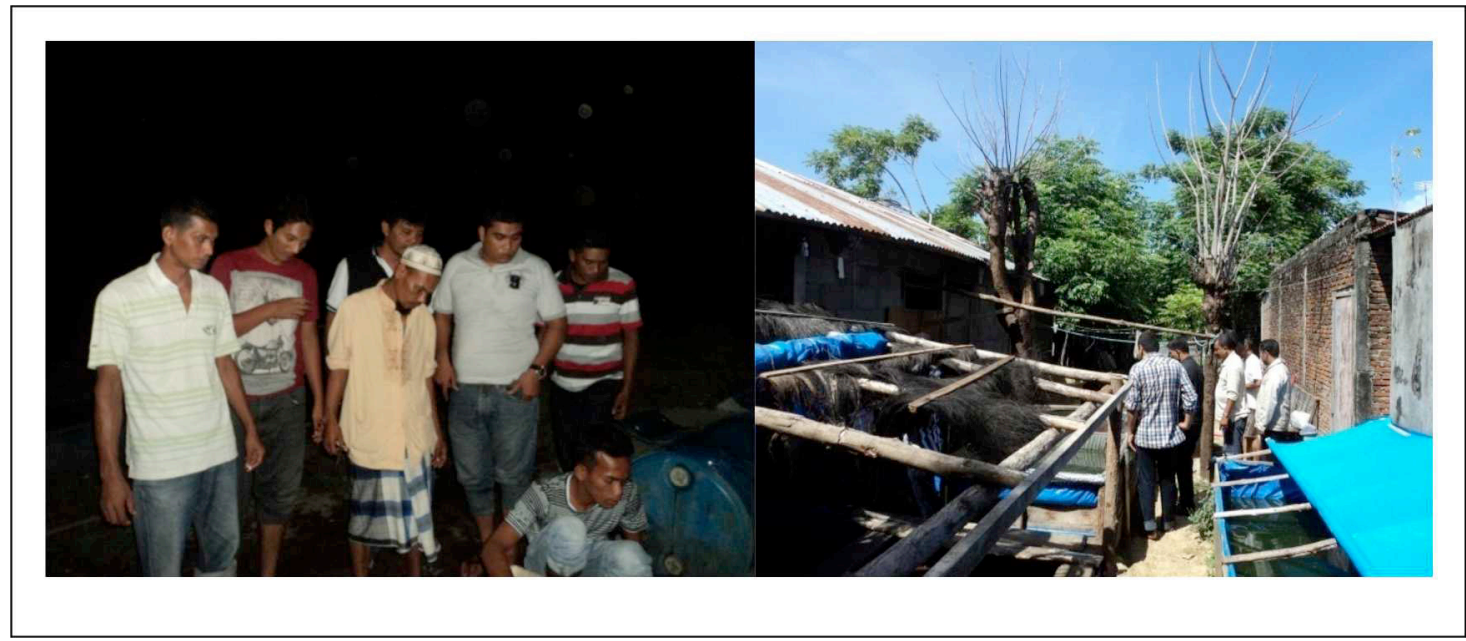

Gambar 2. Peserta Kegiatan Pendampingan Teknologi Perbenihan Ikan Lele

Gambar 2 merupakan lokasi perbenihan skala rumah tangga dengan bahan sederhana yang dikunjungi dalam kegiatan pendampingan teknologi perbenihan dan pembesaran ikan lele. Hasil kunjungan tersebut telah memberi wawasan kepada peserta bahwa perbenihan ikan lele dapat dilakukan di kawasan yang terbatas seperti pekarangan/halaman rumah, rumah tinggal dan lahan kosong. Selain itu, peserta dapat berkomunikasi langsung dengan pemilik lahan yang sederhana tersebut yang melakukan perbenihan yang dijadikan sebagai narasumber dalam kegiatan ini.

Terdapat beberapa hal yang harus diperhatikan dalam pengelolaan induk dalam perbenihan lele. Induk lele yang dijadikan bahan adalah jenis lele phyton yang sudah diseleksi berdasarkan syarat yang ditetapkan yaitu sehat, bentuk tubuh tidak bengkok, umur lele kurang dari 8 bulan, bobot tubuh $800-1.200$ gram (betina) dan 1.000 gram (kurang dari atau sama dengan berat bobot induk betina) untuk induk jantan. Syarat wadah induk lele, tidak ada ketentuan khusus. Akan tetapi, untuk menampung ukuran induk $70-120 \mathrm{~kg}$ diperlukan ketinggian air $80-100 \mathrm{~cm}$. Selain itu, untuk merangsang kematangan gonad dan mempercepat proses pemijahan dapat dilakukan dengan 3 (tiga) cara, yaitu memijah secara alami, buatan dan metode dingin panas.
Kegiatan perbenihan lele dapat dilakukan juga dengan teknik pemijahan buatan. Teknik pemijahan buatan dengan menyuntik induk merupakan suatu teknik dengan cara merangsang kerja hormon dengan menyuntikkan hormon pada induk lele agar proses matang gonad dapat dipercepat.

\section{Pendampingan Teknologi Pengolahan Hasil Perikanan}

Pendampingan teknik pengolahan hasil perikanan merupakan kegiatan yang bertujuan untuk mengoptimalkan pemanfaatan hasil perikanan yang berada pada daerah tersebut. Paket teknologi pengolahan hasil perikanan yang disampaikan oleh narasumber yang berasal dari Balai Besar Industri Agro Bogor, Badan Pengkajian Kebijakan Iklim dan Mutu Industri, Kementerian Perindustrian Republik Indonesia.

Materi pendampingan teknologi pengolahan hasil perikanan yang diberikan KIMBis yaitu sebanyak 7 (tujuh) materi. yaitu : teori sanitasi, teori penanganan dan pengolahan perikanan, teknik pembuatan bandeng tanpa duri, pembuatan kerupuk ikan/udang, teknik pembuatan snack, teknik pengeringan ikan hasil olahan dan teknik penggorengan ikan hasil olahan, serta diskusi tentang hasil pendampingan dan pengawalan IPTEK pengolahan hasil perikanan (Tabel 2).

Tabel 2. Materi Pendampingan Pengolahan Hasil Perikanan di KIMBis Kota Banda Aceh, Tahun 2012.

\begin{tabular}{ll}
\hline I. & MATERI \\
II. & Teori sanitasi dan terainitas \\
1. Tennik pembuanan dan pengolahan hasil perikanan \\
2. Teknik pembuatan kerupuk ikan/ udang \\
3. Teknik pembuatan snack ikan \\
1. Teknik pengeringan ikan hasil olahan \\
2. Teknik pengorengan ikan hasil olahan \\
\end{tabular}

Sumber: Bahan Presentasi Kegiatan, 2012 
Pelaksanaan pendampingan dan pengawalan teknologi pengolahan tersebut akan mendorong masyarakat dapat menciptakan peluang usaha dengan optimal. Jika dibandingkan antara pendampingan teknologi perbenihan dan pengolahan hasil perikanan, kegiatan pengolahan hasil perikanan terlihat berjalan lebih dinamis dibandingkan kegiatan perbenihan. Hal ini disebabkan sebagian peserta merupakan pelaku usaha (pengolah) yang sudah memiliki produk olahan dengan segmen pasar tertentu. Bahkan ada peserta yang pernah mengikuti pameran hasil olahan ke Jepang dan menjadi juara nasional pengolah hasil perikanan. Walaupun demikian, para peserta masih antusias mengikuti pendampingan karena kegiatan ini dapat membuat diversifikasi hasil pengolahan produk aneka ikan. Peserta pendampingan teknologi pengolahan produk aneka ikan dapat dilihat pada Gambar 3.

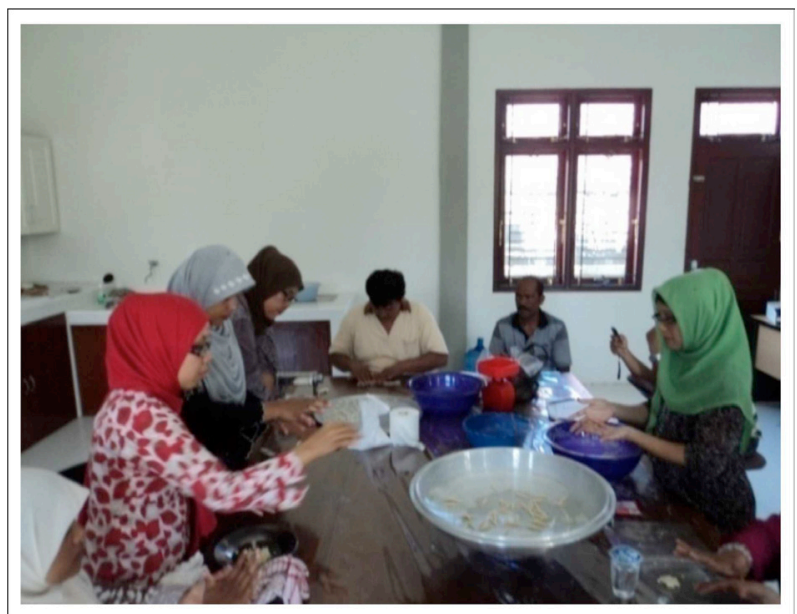

Gambar 3. Peserta Pendampingan Teknologi Pengolahan Hasil Perikanan.

Tingginya minat peserta pendampingan teknologi pengolahan ikan juga terbukti dengan kemampuan para peserta menyediakan semua fasilitas pendukung kegiatan. Artinya konsep KIMBis yang disampaikan kepada kelompok sasaran bahwa lembaga ini adalah wadah dimana partisipasi besar peserta dalam kegiatan akan memberi manfaat bagi peserta itu sendiri.

Produk hasil pendampingan teknologi pengolahan hasil perikanan yang diberikan adalah produk aneka kerupuk ikan, chip/ snack ikan, bandeng presto, dan bandeng tanpa duri. Bahan baku yang digunakan untuk pengolahan hasil perikanan adalah ikan tenggiri, ikan kakap, kambing-kambing dan ikan bandeng. Hasil pendampingan teknologi pengolahan hasil perikanan disajikan pada Gambar 4.

Rasa produk yang diperkenalkan adalah standar agar dapat dikembangkan oleh para peserta., Hal tersebut dilakukan agar para peserta menyesuaikan dengan selera di setiap daerah. Agar produk hasil olahan ikan yang diproduksi oleh pelaku usaha dapat diterima pasar dengan baik maka citra rasa produk yang dihasilkan harus dapat disesuaikan dengan selera konsumen yang menjadi target pasar.

Perlu dicatat bahwa proses pengolahan yang dilakukan tidak menggunakan bahan dan zat kimia yang berbahaya. Sebagai contoh dalam kegiatan pengolahan tidak menggunakan penyedap rasa dan bahan pewarna sebagai bagian dari bumbu pembuatan kerupuk. Selain itu, didorong untuk membuat produk dari bahanbahan asli yang berasal dari daerah setempat sehingga memiliki ciri khas tersendiri.

Pengamatan menunjukkan bahwa peserta pendampingan teknologi pengolahan hasil perikanan cenderung tidak mengalami kendala yang berarti dalam melakukan kegiatan tersebut. Peserta sangat berperan aktif, bekerja sama dengan baik dan masingmasing anggota mengerti apa yang harus dilakukan. Walaupun terdapat beberapa peserta yang belum menguasai teknik sederhana pengolahan ikan yang baik dan benar seperti cara mencampur bahan, melakukan steam dan menggoreng produk. Namun kerja sama antar peserta menyebabkan teknik tersebut dapat dikuasai sehingga peserta kegiatan puas terhadap kegiatan pendampingan tersebut.

Selain itu, satu hal yang menarik adalah terlibatnya salah satu peserta kegiatan pendampingan teknologi pengolahan hasil perikanan menjadi pemeran utama dari kegiatan pemberdayaan perempuan yang diprogramkan oleh stasiun TV NHK Jepang. Selama pendampingan berlangsung, semua proses kegiatan yang dilakukan oleh peserta direkam oleh TV NHK Jepang tersebut. Hal ini tentu akan menjadikan KIMBis sebagai salah satu kegiatan Lingkup Balitbang KP yang sudah mendunia yang sesuai dengan nama klinik IPTEK Mina Bisnis Aceh, yaitu "Cakradonya".

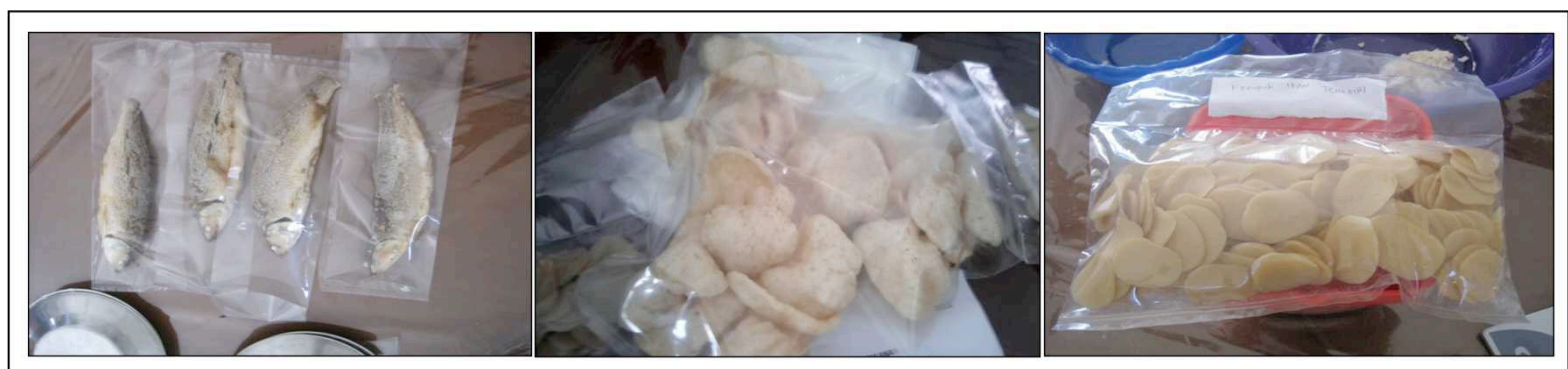

Gambar 4. Hasil dari Kegiatan Pendampingan Teknologi Pengolahan Hasil Perikanan 


\section{Pendampingan Teknologi Perbengkelan Mesin Kapal}

KIMBis Cakradonya melakukan kegiatan pendampingan dan pengawalan IPTEK tentang perbengkelan dalam rangka meningkatkan keterampilan rumah tangga nelayan. Kegiatan pendampingan dan pengawalan IPTEK ini telah dilakukan pada tanggal 28 - 29 November 2012. Kegiatan tersebut diikuti oleh 11 peserta yang terdiri dari nelayan dan anak-anak nelayan. Pendampingan dan pengawalan teknologi perbengkelan disampaikan oleh salah satu pengajar Sekolah Usaha Perikanan Menengah (SUPM) Negeri Ladong yang berlokasi di Kabupaten Aceh Besar.

Kegiatan pendampingan dan pengawalan IPTEK tentang perbengkelan ini difasilitasi oleh pengurus KIMBis Pusat dan pengurus KIMBis lokasi. Adapun narasumber atau instruktur dalam pendampingan ini terdiri dari 2 (dua) orang, yaitu seorang pengajar di SUPM Negeri Ladong dan seorang teknisi yang memiliki bengkel di daerah Desa Punge Blang Cut, Banda Aceh.

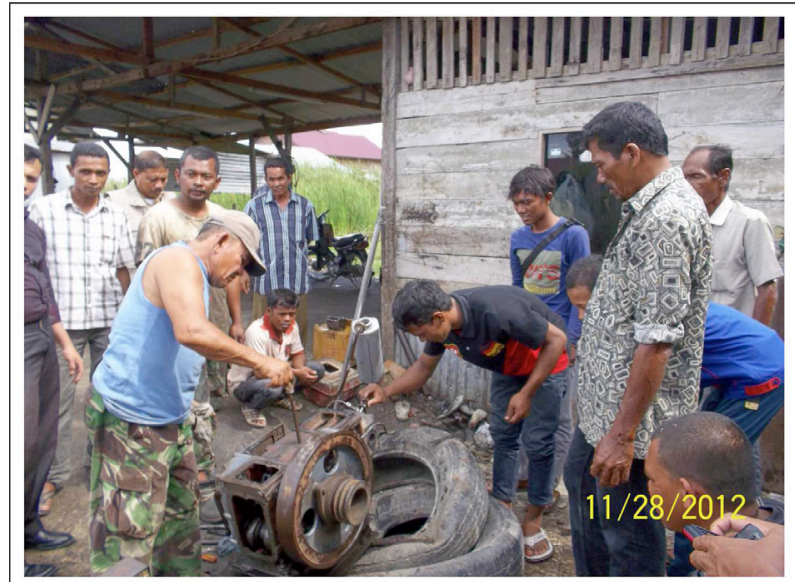

Gambar 5. Narasumber dan Peserta dalam Peningkatan Keterampilan Perbengkelan.

Metode peningkatan keterampilan perbengkelan dilakukan melalui presentasi teori singkat, praktik di bengkel, diskusi kelompok dan diskusi umum yang melibatkan semua peserta, narasumber, pengurus KIMBis dan Dinas Kelautan Perikanan dan Pertanian Kota Banda Aceh.

Materi peningkatan keterampilan perbengkelan yang diberikan narasumber sebanyak 2 (dua) materi besar. yaitu kontruksi motor diesel dan prinsip kerja motor diesel. Materi konstruksi motor diesel terdiri atas komponen utama motor diesel dan sistem penunjang motor diesel. Materi prinsip kerja motor diesel terdiri atas karakteristik motor diesel dan prinsip kerja motor diesel 4 langkah. Untuk memudahkan peserta dalam memahami materi, narasumber memberikan animasi yang menarik tentang prinsip kerja motor dengan 1 silinder dan multi silinder. Pemberian materi dilakukan dua arah dimana peserta langsung bertanya di tengah pemaparan materi yang diberikan oleh narasumber.
Tabel 3 berikut menampilkan materi yang diberikan narasumber pada kegiatan peningkatan keterampilan perbengkelan.

Tabel 3. Materi Peningkatan Keterampilan Perbengkelan KIMBis Cakradonya, Banda Aceh.

\section{MATER}

I. Teori kontruksi motor diesel

1. Klasifikasi komponen motor diesel

2. Komponen utama motor diesel

3. Sistem penunjang motor diesel

II. Teori Prinsip Kerja Motor Diesel

1. Karakteristik motor diesel

2. Prinsip kerja motor diesel 4 langkah

3. Animasi prinsip kerja motor diesel 1 silinder

4. Animasi prinsip kerja motor diesel multi silinder

Sumber: Bahan Presentasi Kegiatan, 2012

Materi pendampingan diberikan melalui pemaparan teori disampaikan di kelas dan penjelasan komponen motor diesel dilakukan pada bengkel di Desa Punge Blang Cut. Pada saat pemberian materi di dalam kelas, peserta aktif mengikuti pendampingan dengan bertanya di sela-sela pemaparan. Sebagian besar pertanyaan yang diajukan berkenaan dengan pengalaman peserta dalam memperbaiki atau menggunakan mesin dompeng di kapal ikan mereka. Selain itu, penyajian materi juga diselingi dengan tayangan yang bertujuan untuk memotivasi dan mencarikan suasana belajar yang umumnya berjalan serius dan menegangkan.

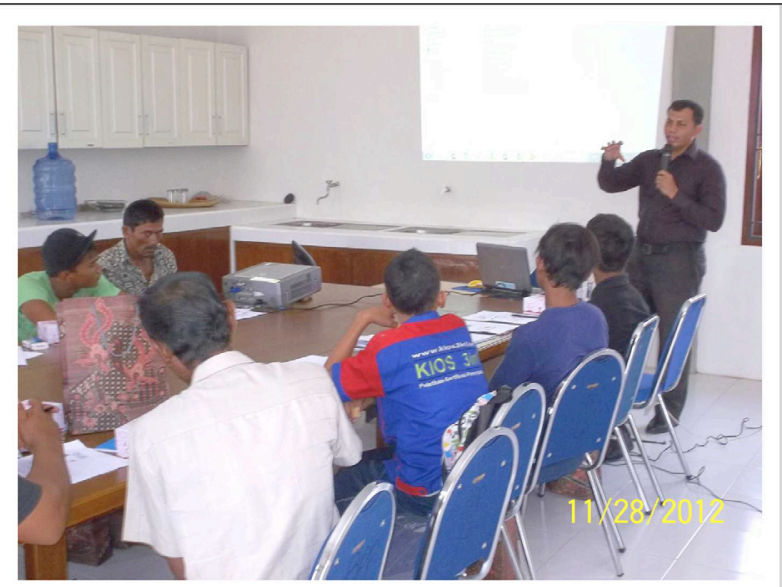

Gambar 6. Pemberian Materi Berupa Teori di Dalam Ruangan.

Pemberian materi kemudian diberikan melalui praktek langsung di bengkel milik salah seorang narasumber. Cara ini dilakukan untuk memperkenalkan komponen motor diesel secara langsung kepada para peserta sehingga materi yang telah diberikan sebelumnya dapat lebih mudah dipahami. 


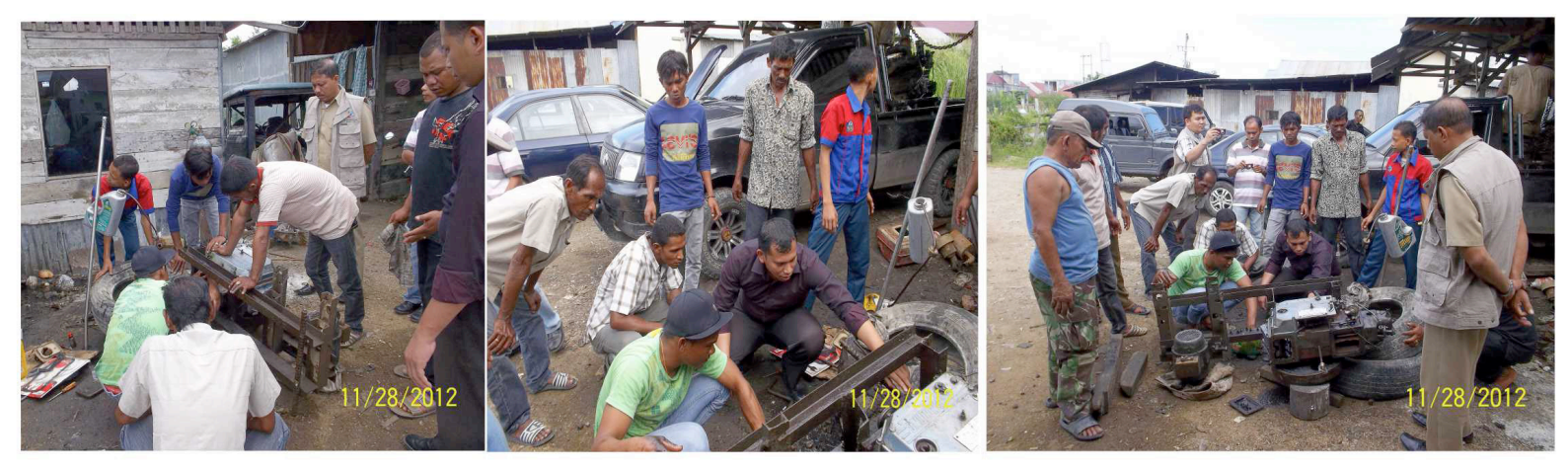

Gambar 7. Kegiatan Pendampingan Penumbuhan Mata Pencaharian Alternatif di Bengkel.

Selanjutnya, peserta juga secara langsung ditunjukkan prinsip kerja dari motor diesel 4 langkah seperti yang diberikan pada materi di ruangan sebelumnya. Pengenalan ini dilakukan dari langkah awal hingga mesin atau motor dapat hidup yang siap dioperasikan. Pada saat pembelajaran di lapangan, semua peserta berperan aktif dengan ikut serta memasang suku cadang dan menghidupkan mesin hingga hidup.
Kegiatan ini dilanjutkan dengan mempraktikkan materi yang telah diterima dengan memanfaatkan mesin dompeng yang rusak. Untuk kegiatan ini, peserta diberikan 2 (dua) buah mesin dompeng untuk dibongkar dan dipasang kembali hingga mesin dapat berfungsi. Untuk itu, peserta dibagi menjadi 2 (dua) kelompok agar setiap peserta memiliki kesempatan yang sama dalam membongkar mesin karena pembelajaran secara langsung cenderung lebih

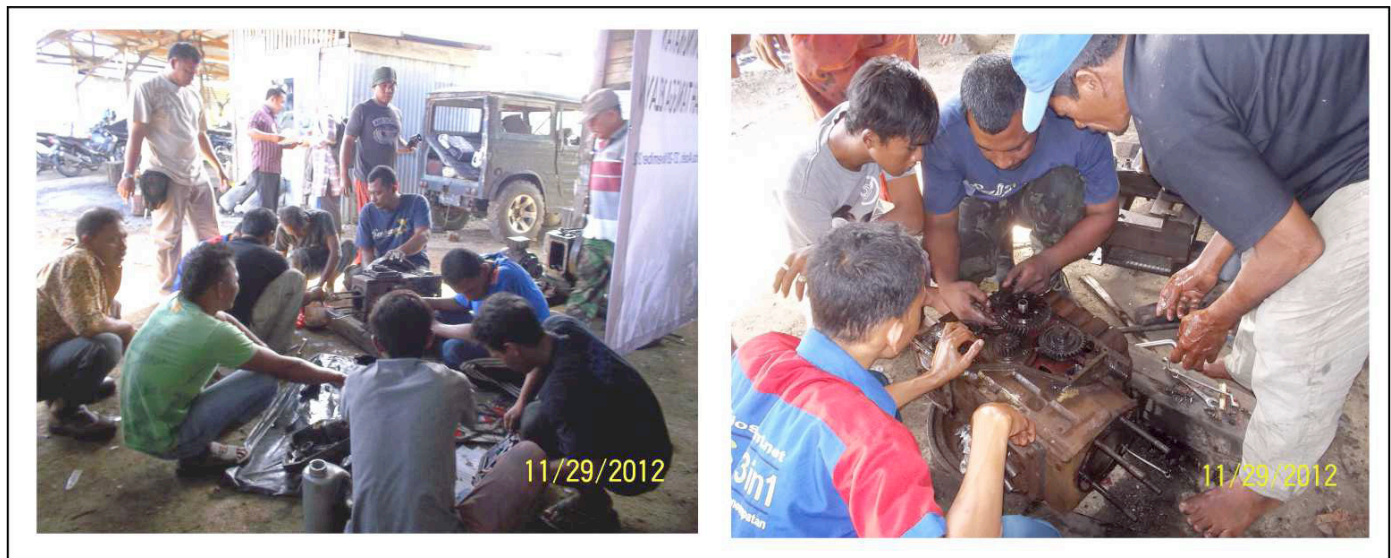

Gambar 8. Kegiatan Praktik Langsung Perbaikan Mesin Dompeng di Bengkel.

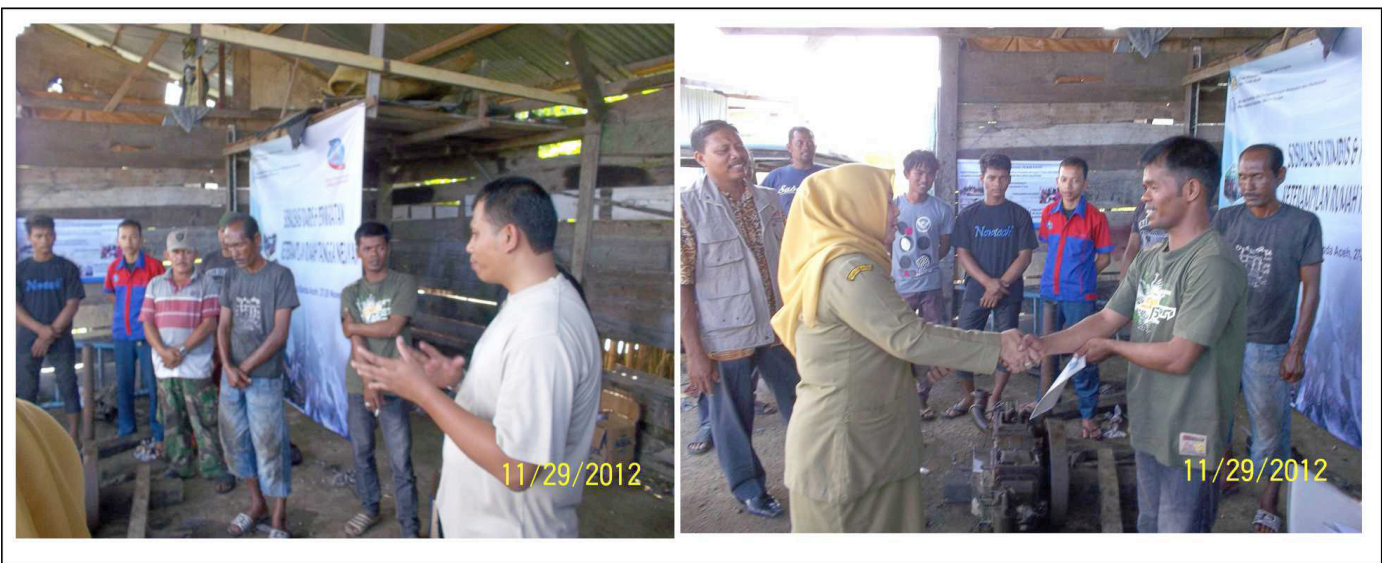

Gambar 9. Diskusi Antara Peserta dan Narasumber Serta Penyerahan Sertifikat oleh Unsur Dinas KPP Kota Banda Aceh kepada Peserta. 
efektif dibandingkan pembelajaran secara teoritis. Salah satu mesin yang digunakan sebagai alat pendampingan adalah mesin dompeng milik salah satu peserta pendampingan yang telah rusak selama 5 bulan yang menyebabkan peserta tersebut tidak dapat melaut. Selama proses pendampingan berjalan, semua peserta mengambil peran dalam perbaikan mesin tersebut sehingga pada akhir pendampingan, mesin dompeng tersebut dapat dihidupkan dan siap dioperasikan. Untuk itu, pemilik mesin tersebut sangat berterima kasih karena di samping telah diberi bekal keterampilan perbaikan mesin, dirinya juga dapat melaut kembali karena mesin dompengnya dapat beroperasi lagi.

Ketertarikan minat peserta terhadap setiap materi dan praktik yang dilakukan merupakan indikator utama bagi pelaksanaan pendampingan dan pengawalan

\section{EVALUASI KINERJA PENDAMPINGAN TEKNOLOGI}

Dari hasil pengamatan kegiatan pendampingan dan pengawalan teknologi yang dilakukan, terlihat bahwa baik secara individu, kelompok maupun instansi yang terkait dalam kegiatan tersebut merasakan kepuasan yang tinggi terhadap rangkaian kegiatan KIMBis tersebut. Ketertarikan minat peserta terhadap setiap materi dan praktik yang dilakukan merupakan indikator utama bagi pelaksanaan pendampingan dan pengawalan teknologi perbenihan lele, pengolahan hasil-hasil perikanan, dan perbengkelan mesin kapal. Selain itu, peran aktif setiap peserta dalam mengikuti rangkaian kegiatan tersebut merupakan indikator lain yang dapat dinilai tingkat kesadaran dan kepuasan dari kegiatan tersebut. Nilai persepsi peserta terhadap kegiatan pendampingan dan pengawalan IPTEK KIMBis di Banda Aceh dapat dilihat pada Tabel 4.

Tabel 4. Persepsi Peserta Terhadap Kegiatan Pendampingan dan Pengawalan IPTEK KIMBis di Kota Banda Aceh.

\begin{tabular}{lccc} 
Kategori & $\begin{array}{c}\text { Persepsi Penilaian } \\
\text { Pembudidaya (\%) }\end{array}$ & $\begin{array}{c}\text { Persepsi Penilaian } \\
\text { Pengolah (\%) }\end{array}$ & $\begin{array}{c}\text { Persepsi Penilaian } \\
\text { Nelayan (\%) }\end{array}$ \\
\hline Peran Pengurus & 100 & 87 & 90 \\
Materi Pelatihan & 92 & 92 & 93 \\
Kemampuan Instruktur & 98 & 100 & 100 \\
Keseriusan Peserta & 85 & 82 & 85 \\
Lain-lain & 51 & 83 & 89 \\
\hline
\end{tabular}

Sumber: Data primer, 2012 (diolah)

teknologi peningkatan keterampilan rumah tangga nelayan. Selain itu, peran aktif setiap peserta dalam mengikuti rangkaian kegiatan tersebut merupakan indikator lain yang dapat dinilai tingkat kesadaran dan kepuasan dari kegiatan tersebut. Rangkaian kegiatan tersebut, antara lain proses pengenalan komponen motor, pengenalan prinsip kerja dan praktik langsung dalam perbaikan mesin dompeng. Oleh karena itu, pendampingan dan pengawalan teknologi tersebut sesuai dengan apa yang menjadi harapan peserta kegiatan.

Dalam dinamika kelompok, peserta menunjukkan komunikasi yang berlangsung sangat dinamis dan komunikatif serta hasil akhir praktik kegiatan yang diberikan mendapatkan hasil yang sangat memuaskan. Hal ini disebabkan oleh karena beberapa faktor yang terjadi, yaitu peserta memiliki minat dan ketertarikan di bidang yang sama dan juga karena peserta saling bahu membahu dalam melakukan perbaikan mesin sesuai dengan arahan dan instruksi narasumber. Indikator yang dapat dijadikan ukuran adalah peserta berhasil menghidupkan mesin dompeng yang telah lama rusak sehingga mampu memberi manfaat bagi pemilik mesin dalam mencari nafkah.
Berdasarkan tabel 4, rata-rata peserta menilai pendampingan teknologi yang dilakukan telah sangat baik. Secara keseluruhan, materi yang diberikan dinilai sudah sesuai dengan kebutuhan peserta. Instruktur yang memberikan materi juga dinilai mampu mentransfer pengetahuan dan keterampilan kepada peserta. Peserta menilai kemampuan instruktur dalam mentransfer ilmunya berkisar $98 \%-100 \%$. Kesiapan pengurus dalam pelaksanaan pengawalan juga rata-rata sudah baik, khususnya pada pelatihan pengolahan dan perbengkelan mesin kapal. Sementara untuk aspek peserta pelatihan masih dinilai cukup baik. Persepsi peserta terhadap peserta yang mengikuti pelatihan berkisar antara $82 \%-85 \%$. Angka tersebut menunjukkan jumlah peserta yang diperlukan agar lebih banyak dan masyarakat di luar perikanan juga diikutsertakan karena materi yang diberikan sangat bermanfaat bagi pengembangan ekonomi masyarakat. Perlu dicatat bahwa peralatan dan bahan praktik yang disediakan pengurus dinilai masih terbatas sehingga aspek ini yang harus terus diperbaiki guna suksesnya kegiatan pengawalan teknologi yang diberikan. Oleh sebab itu, setiap kegiatan harus dilakukan kerja sama dengan instansi terkait untuk menyediakan peralatan dan bahan. 


\section{KESIMPULAN}

Pendampingan dan pengawalan teknologi dalam rangka meningkatkan keterampilan rumah tangga nelayan secara umum berjalan dengan baik dan lancar. Kegiatan pendampingan telah mampu meningkatkan keterampilan nelayan dan keluarganya dalam memperbaiki mesin dompeng yang seharihari digunakan untuk melaut. Peserta pendampingan mengharapkan keberlanjutan dari pendampingan yang telah dilakukan dengan menambah pengetahuan karena pendampingan ini dinilai sangat bermanfaat dalam menunjang kegiatan penangkapan yang dilakukan.

Peran Dinas Kelautan Perikanan dan Pertanian, pengurus KIMBis pusat dan pengurus KIMBis Kota Banda Aceh serta narasumber dalam pendampingan dan pengawalan teknologi sangat menentukan keberhasilan program ini. Peran aktif Dinas KPP Kota Banda Aceh diharapkan lebih baik pada kegiatan-kegiatan KIMBis selanjutnya karena kegiatan pemberdayaan masyarakat bukan hanya tanggung jawab KIMBis semata, melainkan juga tanggung jawab SKPD-SKPD di Kota Banda Aceh termasuk Dinas KPP Kota Banda Aceh. Ke depan juga dapat dijajaki kerja sama dengan SUPM Negeri Ladong dalam melakukan pendampingan dan pengawalan teknologi karena selama ini SUPM sebagai lembaga pendidikan juga melakukan pelatihan bagi masyarakat perikanan.

Dari segi evaluasi pelaksanaan kegiatan pendampingan dan pengawalan IPTEK pada KIMBis Cakradonya sudah berjalan dengan baik. Hal ini dapat dilihat dari tingkat minat dan antusias peserta kegiatan dalam mengikuti rangkaian kegiatan pendampingan. Kendala ketersediaan bahan dan peralatan menjadi pembelajaran bagi pengurus KIMBis dalam menyelenggarakan kegiatan berikutnya. Terkait dengan penyediaan bahan dan peralatan maka KIMBis akan bersinergi dengan SKPD-SKPD terkait di lingkup Kota Banda Aceh dalam melakukan kegiatan pendampingan dan pengawalan teknologi. Hal ini sangat penting dilakukan untuk mencapai tujuan yang diharapkan.

\section{DAFTAR PUSTAKA}

Badan Pusat Statistik Kota Banda Aceh. 2012. Banda Aceh Dalam Angka 2012. Badan Pusat Statistik Kota Banda Aceh. Banda Aceh.

Commothio. 2010. Letak Geografis. http://www. bandaacehkota.go.id/index.php/ extensions/ data-geografis/letak-geografis, diakses pada tanggal 22 Agustus 2012.

Dewanto, H. 2004. Pemberdayaan Masyarakat Pedesaan Berbasiskan Masyarakat Terpencil. Badan Perencanaan Pembangunan Nasional. Jakarta.

Dinas Kelautan Perikanan dan Pertanian Kota Banda Aceh. 2012. Potensi Bidang Kelautan dan Perikanan. Dinas Kelautan Perikanan dan Pertanian Kota Banda Aceh. Banda Aceh.

Drajat, E.U. 2013. Transformasi Struktural, diunduh dari http://estuungguldrajat.blogspot.com/2013/04/transformasi-struktural.html pada tanggal 25 Juli 2013.

Permendagri RI Nomor 7 Tahun 2007 Tentang Kader Pemberdayaan Masyarakat. Fokus Media. Bandung.

Sari, N., F. Miralka, F. Hasudungan, L. Muslihat dan N. Suryadiputra. 2006. Penilaian Data Lingkungan Pasca Tsunami di Provinsi Nanggroe Aceh Darussalam. Laporan Teknis. Wetlands International - Indonesia Programme. Bogor. (Tidak Dipublikasikan).

Semiaji. 2011. Strategi Pembangunan Masyarakat Melalui Pelibatan Partisipasi Masyarakat Dalam Pembangunan. Bunga Rampai Administrasi Publik. Lembaga Administrasi Negara. Jakarta.

Sutoro, E. 2002. Pemberdayaan Masyarakat Desa, Materi Diklat Pemberdayaan Masyarakat Desa, Bahan Presentasi yang Diselenggarakan Badan Diklat Provinsi Kalimantan Timur, Samarinda pada Desember 2002.

Zulham, A. 2011. Petunjuk Teknis Pelaksanaan Kegiatan Pengembangan Klinik Iptek Mina Bisnis dalam Mendukung Program Peningkatan Kehidupan Nelayan. Balai Besar Penelitian Sosial Ekonomi Kelautan dan Perikanan. Jakarta. 